\title{
Macroscopic and microscopic analysis of 2 embryos and 1 foetus derived from a sheep (Ovis aries) without breed
}

\author{
Análise macroscópica e microscópica de 2 embriões \\ e 1 feto derivados de ovelha (Ovis aries) sem raça
}

\author{
Isabella Rodrigues FERNANDES ${ }^{1^{*}}$; Marcos Vinicius Mendes SILVA ${ }^{1^{*}}$; Fabiele Baldino RUSSO ${ }^{1^{*}}$; \\ João Leonardo Rodrigues Mendonça DIAS ${ }^{1}$; Dilayla Kelly de ABREU ${ }^{1}$; Graciela Conceição PIGNATARI'; \\ Maria Angélica MIGLINO루 Patrícia Cristina Baleeiro BELTRÃO-BRAGA ${ }^{1,2}$ \\ ${ }^{1}$ Universidade de São Paulo, Faculdade de Medicina Veterinária e Zootecnia, Departamento de Cirurgia, São Paulo - SP, Brazil \\ ${ }^{2}$ Universidade de São Paulo, Escola de Artes, Ciências e Humanidades, Departamento de Obstetrícia, São Paulo - SP, Brazil
}

\begin{abstract}
The interest in embryology, the science of the development of a zygote into a completely developed foetus, has increased greatly in recent years due to a number of studies involving embryonic and induced pluripotent stem cells. In addition, the development of techniques such as cloning has aided to understand the critical events that occur during embryonic development. In this study, we describe the morphology of two sheep embryos and one foetus using macroscopic and microscopic techniques. We investigated sheep without defined breed on days 24, 32, and 50 of gestation (estimated by crown-rump length $[\mathrm{CR}]$ ). Macroscopically, we observed the development of E1 (24 days), with visible optic vesicle, but without retinal pigmentation and the forelimbs bud in development. In the E2 (32 days), we noticed the presence of optic retinal pigmentation and forelimbs more developed in comparison with E1. As expected, F1 revealed an eyeball already covered and the forelimbs developed. Meanwhile, microscopic analysis revealed somite, ventricle, atrium, and oral cavity in development in E1. However, in F1 we were able to identify more complex structures, such as ossification in the spine, ventricle, atrium, intraventricular septum, pericardial sac, and oral cavity with tongue. This work brings more precise and detailed data on the morphological characteristics of the major organ systems (nervous, circulatory, respiratory, digestive, and urinary) at each embryonic and foetal stage analysed.
\end{abstract}

Keywords: Embryology. Sheep. Embryos. Foetus. Embryonic development.

\section{Resumo}

O interesse em Embriologia, a ciência do desenvolvimento de um zigoto em um feto completamente desenvolvido, tem aumentado consideravelmente nos últimos anos devido a uma série de estudos envolvendo células-tronco pluripotentes embrionárias e induzidas. Além disso, o desenvolvimento de técnicas como a clonagem tem ajudado a compreender os eventos críticos que ocorrem durante o desenvolvimento embrionário. Neste estudo, descrevemos a morfologia de dois embriões de ovinos e um feto utilizando técnicas macroscópicas e microscópicas. Obtivemos ovelhas sem raça definida com 24, 32 e 50 dias de gestação (estimado pelo método de Crown-Rump, CR). Os conceptos foram mensurados, pesados e caracterizados a olho nu. Macroscopicamente, observamos o desenvolvimento dos embriões E1 (24 dias), apresentando globo ocular sem pigmentação de retina e broto do membro torácico e pélvico. Já o E2 (32 dias), apresentava globo ocular com pigmentação na retina e os membros torácicos e pélvicos mais desenvolvidos. $\mathrm{O}$ $\mathrm{F} 1$ apresentou olhos cobertos com uma membrana e membros torácicos e pélvicos mais desenvolvidos. Enquanto isso, microscopicamente observamos no E1 somitos, ventrículo, átrio e cavidade oral ainda em desenvolvimento. Porém, no F1 já era possível observar ossificação da coluna espinhal, coração com estruturas mais complexas, como ventrículo, átrio, septo interventricular e saco pericárdio. Além disso, na cavidade oral observamos a formação da língua. Este trabalho fornece informações precisas e detalhadas sobre as características morfológicas dos principais órgãos dos sistemas (nervoso, circulatório, respiratório, digestivo e urinário) em cada fase embrionária e fetal analisadas.

Palavras-chave: Embriologia. Ovelhas. Embriões. Feto. Desenvolvimento embrionário.

${ }^{\star}$ Estes autores contribuíram igualmente para o trabalho. 
Correspondence to:

Patrícia Cristina Baleeiro Beltrão-Braga

Universidade de São Paulo, Escola de Artes, Ciências e

Humanidades, Departamento de Obstetrícia

Rua Arlindo Béttio, 1000

CEP 03828-000, São Paulo, SP, Brazil

e-mail: patriciacbbbraga@usp.br

Received: $17 / 10 / 2016$

Approved: 12/05/2017

\section{Introduction}

Sheep (Ovis aries) were one of the first domesticated animals, with the first herds appearing approximately 9000 B.C. in the Middle East, the cradle of the first civilisations, and then spreading throughout Europe and Asia. Today, more than $1,168,000,000$ head of more than 800 species of sheep are bred throughout the world. The largest producer is Australia, with 166 million head and many high productivity systems. In Brazil, the sheep population exceeds 17 million head and is mostly concentrated in the Northeast (59.2\%) region, followed by the Southern (27.4\%), Central-West (6.1\%), Southeast (3.9\%) and Northern (3.2\%) regions (INSTITUTO FNP, 2006). According to Carneiro (2007), sheep ranching in Brazil is undergoing a rapid technological expansion. However, sheep ranching lacks studies to improve the reproductive yield of these animals, which could consequently increase production by decreasing the reproductive losses resulting from low birth weight and low temperatures occurring during lambing time, especially in the Southern region of the country (RIBEIRO et al., 2002).

Understanding sheep development could be helpful to many applications. Sheep have been used as animal source in several studies, such as cloning, tissue regeneration, and even pathology. Since 1996, sheep have drawn attention of new methodology, using nuclear transfer in a cultured cell line to cloning (CAMPBELL et al., 1996). The idea is not only cloning, but also guaranteeing the survival of the lineage of a particular animal or the improvement of the breed. This methodology opened a new market to cloning sheep, bovine, and others. Comprehending sheep development could help identify diseases during gestation, controlling, preventing, and eliminating diseases, such as pre-natal transmission of scrapie (FOSTER et al., 2013; ADAMS, 2016), intrauterine growth-restriction of the foetus (MUTINATI et al., 2013; HAY et al., 2016), and others.

Sheep gestational period ranges from 140 to 150 days (COUTINHO; SILVA, 1989; PORADA et al., 2005;
MORAES et al., 2008). Data on the biology of sheep development are surprisingly rare and fragmented, and few studies have reported the morphological characteristics of the embryo during gestation (BRYDEN et al., 1972). Due to the importance of embryonic and foetal development for sheep rising, this study aimed at describing the morphological traits of the major organ systems during organogenesis in the embryonic and foetal phases. Using these macroscopic and microscopic analyses, this work could be used as parameter and reference for embryonic and foetal development of sheep.

\section{Materials and Methods}

\section{Animals}

This work was approved by the Ethics Committee on Animal Use of the Faculty of Veterinary Medicine and Animal Science, São Paulo University, number 1713/2009. Two embryos (E1 and E2) with CR-estimated gestational ages of 24 and 32 days, respectively, and one foetus (F1) with CR-estimated gestational age of 50 days, based on the criteria of Evans and Sack (1973), were used in the present study. These specimens were collected during slaughter in a processing plant in Promissão, São Paulo, Brazil (PESSOLATO et al., 2012). The nomenclature used was based on the International Committee on Veterinary Gross Anatomical Nomenclature and on the International Committee on Veterinary Histological and Embryological Nomenclature.

\section{Biometric Data and Macroscopic Analysis}

For age estimations, the embryos and foetus were analysed macroscopically to determine their CR values through measuring of the nuchal crest to the last sacral vertebra. The macroscopic traits of the animals were then described and photographed.

\section{Light Microscopy}

For the light microscopy analysis, the E1 and F1 samples were fixed in $4 \%$ paraformaldehyde and then dehydrated in increasing ethanol concentrations (from $70 \%$ to $100 \%$ ethanol), cleared in xylene, and embedded in paraffin (Histosec, Merck, Berlin, Germany). After processing, the paraffin blocks were cut into $5 \mu \mathrm{m}$ sections on an automatic microtome (RM2165, Leica, Wetzlar, Germany). The sections were placed on slides and incubated at $60^{\circ} \mathrm{C}$. The samples were stained with haematoxylin and eosin (HE), 
Masson's trichrome (MT) or toluidine blue (TB) (TOLOSA et al., 2003). Finally, the morphology of the samples was analysed and photographed under an Olympus BX40 microscope (KS400 Image Analysis System 3.4, Zeiss, Jena, Germany).

\section{Results}

\section{Macroscopic Characterization}

\section{Embryonic Stage}

An optic vesicle lacking retinal pigmentation and a pronounced cervical flexure were observed in the E1 embryo, which had a CR length of $1.13 \mathrm{~cm}$ (Figures 1A and $1 \mathrm{~B})$. The thoracic and pelvic buds were developing but were still paddle-shaped and lacked division of the digits.
The craniocaudal curvature caused the embryo's "C" shape Development of the prosencephalon and mesencephalon could also be seen in the cranial cavity. There was a bulge in the thoracic and abdominal regions, which was likely due to the poor fit of the internal organs in the small embryo (Figures 1A and 1C).

In the E2 embryo, which had a CR length of 2.13 $\mathrm{cm}$ (Figures 1C and 1D), well-developed optic vesicles with pigmented retinae and developing cephalic vesicles (prosencephalon and mesencephalon) in the cranial cavity were observed. The fourth cephalic ventricle and a pronounced cervical flexure were also visible. The thoracic and pelvic limbs were more developed than the E1 embryo and had dividing digits. The elongated tail and nasal region were still not substantially formed (Figures 1C and 1D).
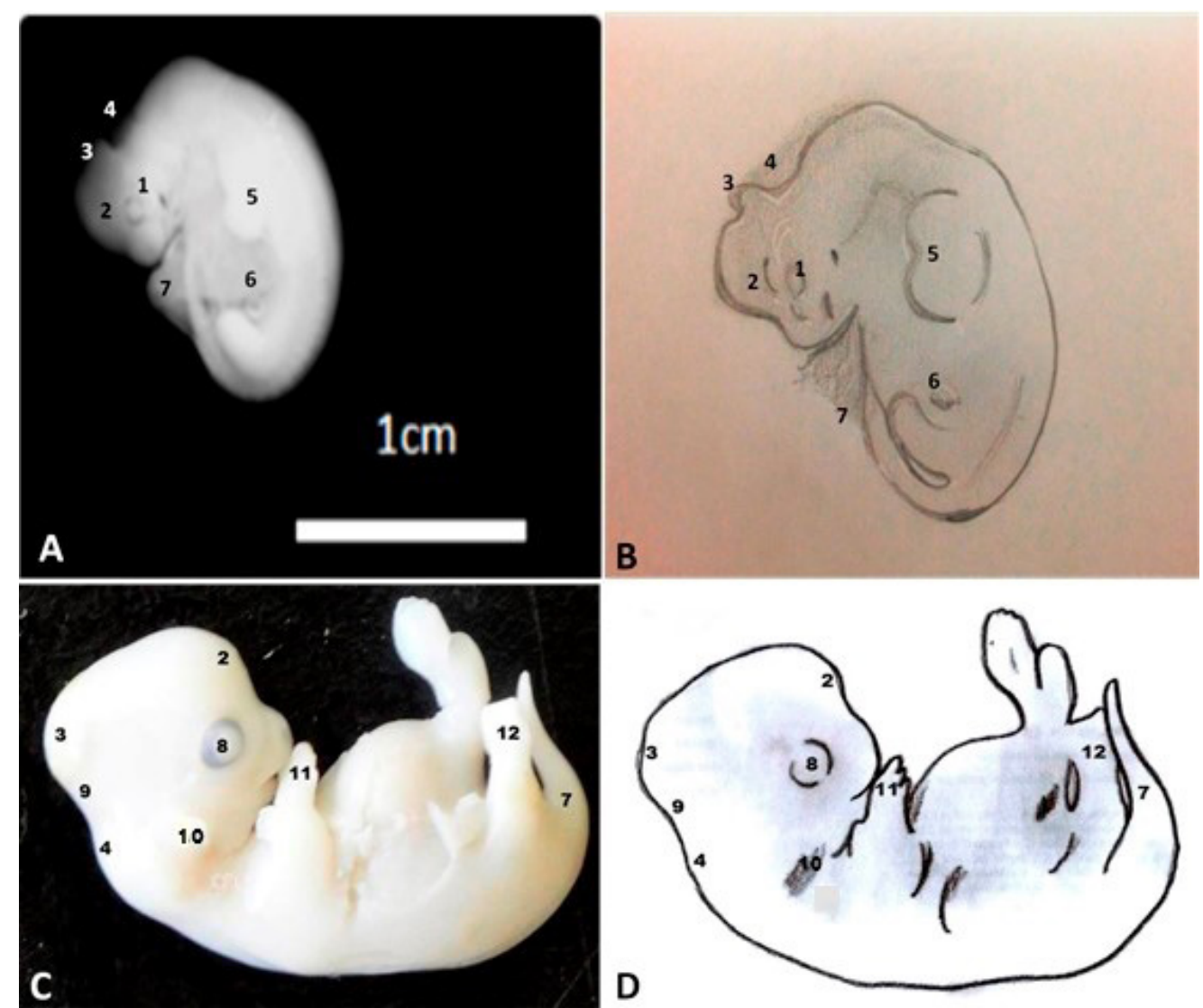

Figure 1 - Photograph and representative drawing of embryos. (A and C) Side-view photograph of the embryo E1 and E2, respectively. (B and D) Representative drawing of embryos E1 and E2, respectively. Where: optic vesicle without retinal pigmentation (1), forebrain (2), midbrain (3), cervical flexure (4), forelimb bud (5), pelvic limb bud (6), tail (7), gallbladder optical retinal pigmentation (8), fourth ventricle (9), optic vesicle (10), forelimb (11), hind limb (12)

\section{Foetal Stage}

The growth and development of the visual structures observed in the embryonic stages were also observed in the foetus, which had a CR length of $5.4 \mathrm{~cm}$ (Figures 2A and $2 \mathrm{~B}$ ). The facial features, such as the eyelids and mouth, were completely formed. The ear chambers were developing and could be found on both sides of the head next to the edge of the cervical region and at the same 
level as the optic vesicles. Both the thoracic and abdominal regions were well developed and were large enough for the internal organs. Thus, the bulge seen during the embryonic stage was not present. When sectioned sagittally, the syntopy of the organs and their respective cavities was apparent (Figure 2C). The thoracic and pelvic limbs were fully developed and looked similar to those of an adult animal. An elongated tail could also be observed in the pelvic region, and the umbilical cord protruded out of the abdominal region (Figures 2A, 2B and 2C). Figure 2C shows the foetal structures in the sagittal sections, including the oral cavity, nasal sinuses, vertebrae, intestinal loops, liver, spinal cord tail, trachea, diaphragm, lung, umbilical pedicle, heart, cerebellum, and brain.

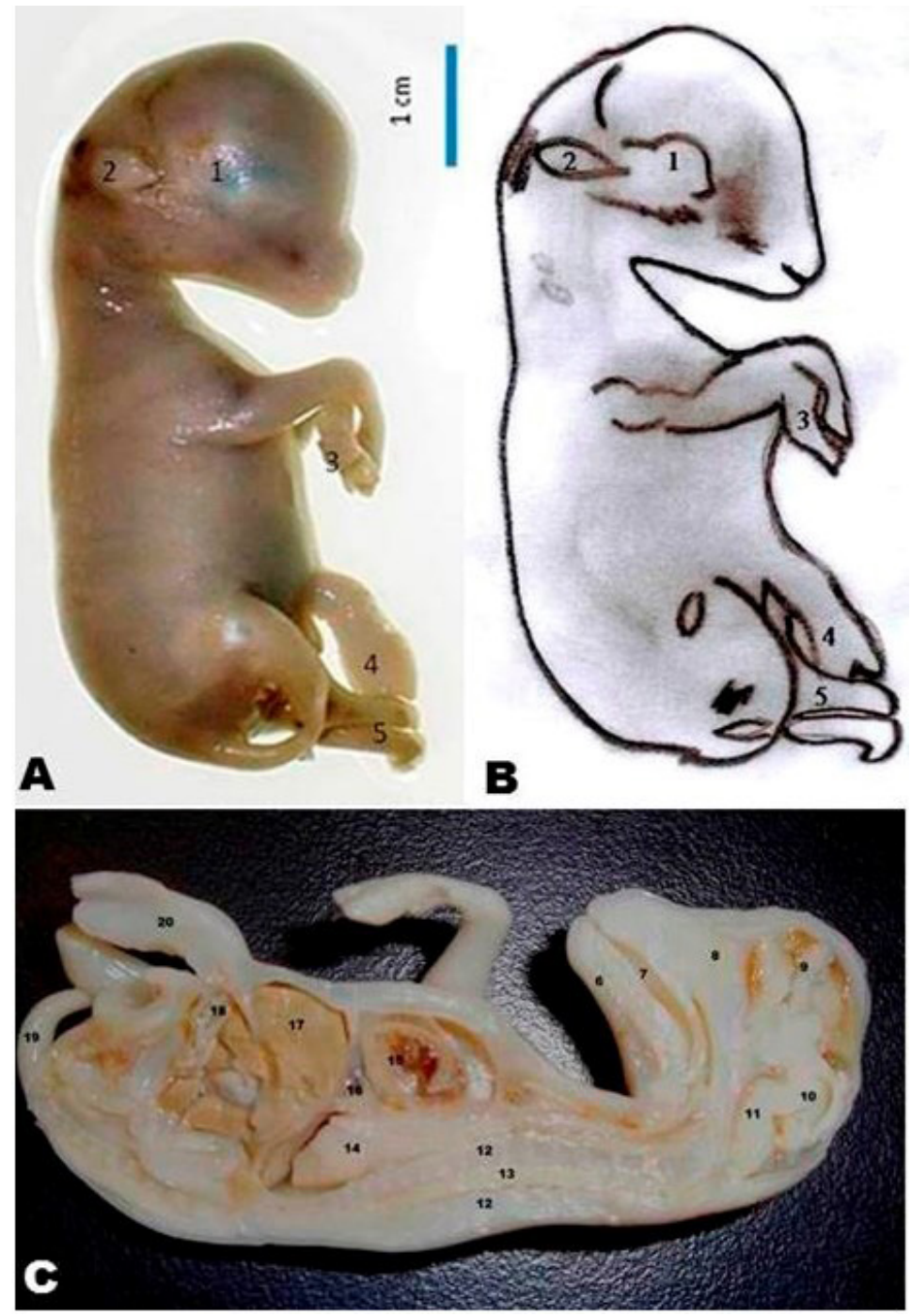

Figure 2 - Photograph and representative drawing of F1 fetus on day 50 of gestation. (A and B), Representative side-view photograph and drawing of $O$ vis aries foetus at 52 days of gestation. (C) Macroscopic photograph of F1 fetus in sagittal view, left side; structures observed: lids covering the eyeball (1), ear (2), forelimb (3), umbilical cord (4), hind limb (5), tongue (6), oral cavity (7), paranasal sinuses (8), brain (9), stemhead (10), cerebellum (11), spine (12), spinal cord (13), lungs (14), heart (15), diaphragm (16), liver (17), intestinal loop (18), tail (19), and umbilical pedicle (20)

\section{Microscopic Analysis Nervous System}

In the 24-days-old embryo (Figure 3A), the prosencephalon (Figure $3 \mathrm{~B}$ ) and the somites that form the precursors of the spinal cord were observed (Figure 3C). These somites were replaced by the spinal cord, and the cranium that was in contact with the dura mater was beginning to ossify in the 50-days-old foetus (Figure 4A). 
The choroid plexus, which consists of an internal connective tissue layer supporting an external layer of flat epithelial cells, was also observed (Figure 4B). Ossification of the vertebrae, including the presence of differentiated cartilage chondrocytes in the mesenchyme, was also observed in F1 (Figure 4C).

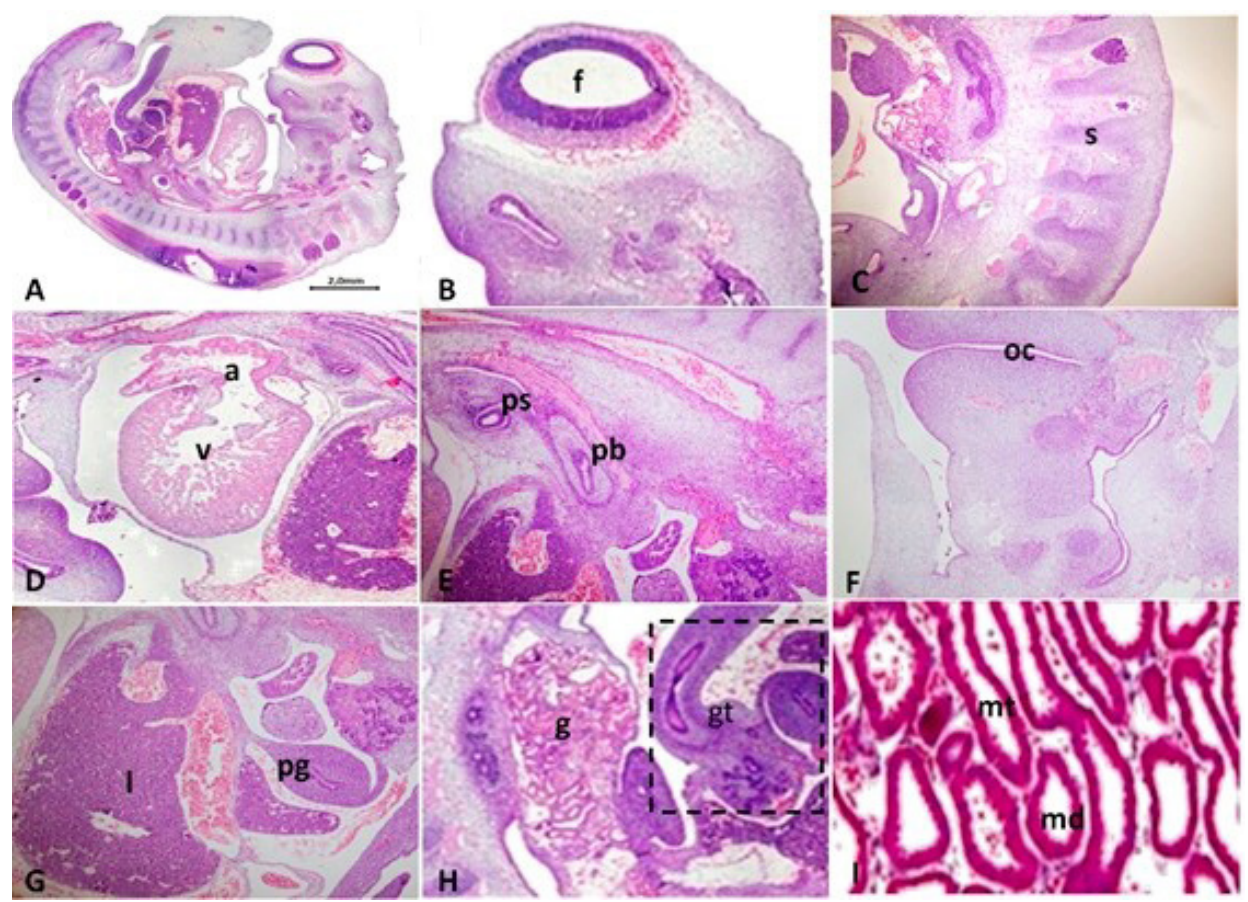

Figure 3 - Histological analysis of E1 with 24 days of gestation. (A) Representation of E1. (B) Forming forebrain (f). (C) Somites (s). (D) Developing heart showing the ventricle (v) and atrium (a). (E) Main pulmonary bud (pb) and secondary pulmonary bud (ps). (F) Oral cavity (oc). (G) Liver (l) and primitive gut (pg). (H) Gonad (g) and gastric tube (gt). (I) Mesonefron, Presence of mesonephric duct (md) and mesonephric tubule (mt). A, $\mathrm{B}, \mathrm{C}, \mathrm{D}, \mathrm{E}, \mathrm{F}, \mathrm{G}$, and $\mathrm{H}$ : 4x magnification after HE staining. I: 10x magnification after TM staining

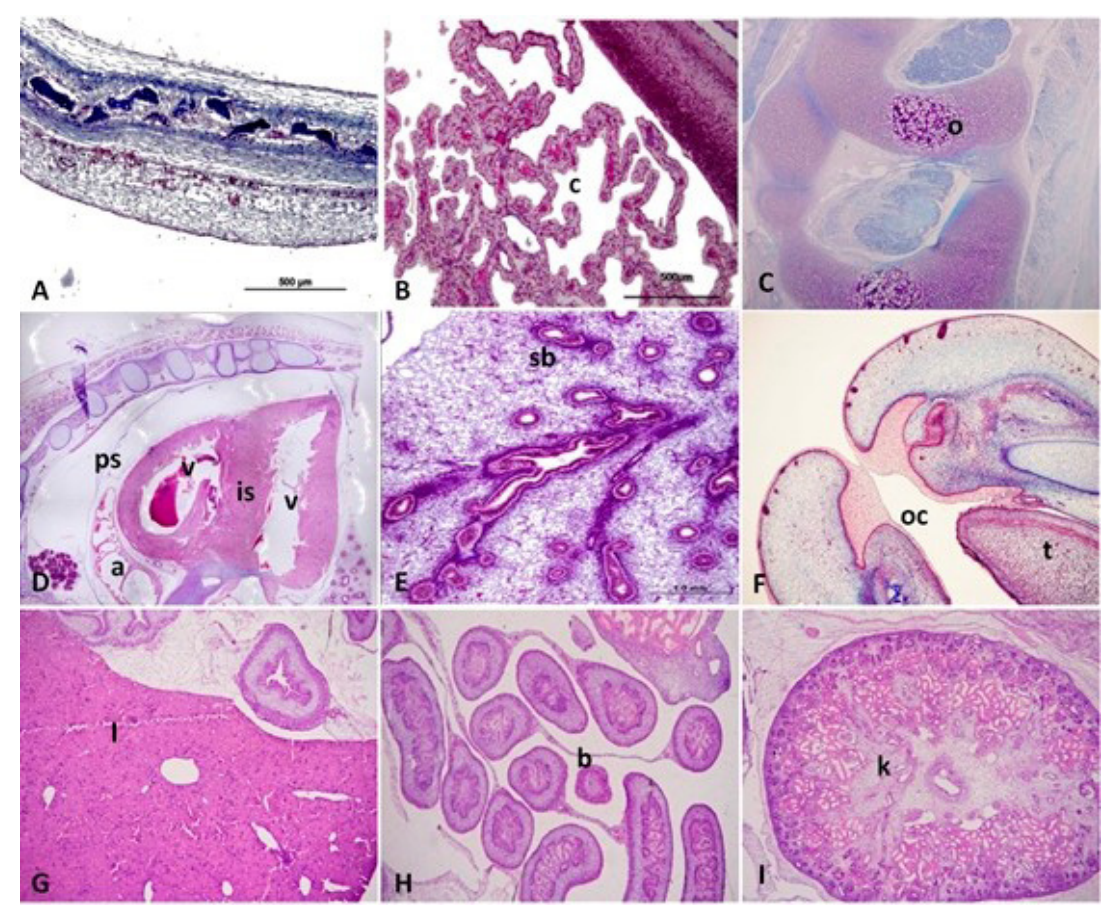

Figure 4 - Histological analysis of F1 with 50 days of gestation. (A) Dura mater. (B) Developing choroid plexus (c). (C) Ossification of the spine (o). (D) Featuring heart ventricle (v), atrium (a), intraventricular septum (is), and pericardial sac (ps). (E) Lung, presence of secondary broncos (sb). (F) Oral cavity (oc) with tongue (t). (G) Liver (l). (H) Bowel (b). (I) Kidney (k). A, B, E, 10x magnification. C, D, F, G, H, I, 4x magnification. A, C, Toluidine blue staining. E) TM. B, D, F, G, H, I, HE staining 


\section{Cardiovascular System}

Ventricle formation was detected in the E1 embryo, although the atria and the major vessels leaving the heart (such as the aorta) were much less formed than in the foetus (Figure 3D). There, we could see more developed atria, ventricles, pericardium, and ventricular septum (Figure 4D).

The formation of secondary bronchial branches could be seen in the E1 embryo (Figure 3E) and in the foetus (Figure 4E). Additionally, in F1 the differentiation of the mesenchyme surrounding the bronchi into condensed mesenchyme and loose mesenchyme was visible. The bronchi consisted of ciliated pseudo stratified epithelium that covered a layer of connective tissue, where many blood vessels that provide nutrients to the organ as a whole could be seen.

\section{Digestive System}

The oral cavity in both E1 and F1 was covered in stratified squamous epithelium and contained a developing tongue (Figures $3 \mathrm{~F}$ and $4 \mathrm{~F}$ ).

In the E1 embryo, the primitive intestinal loops (Figure $3 \mathrm{H}$ ) were covered in mesenchyme but were still developing. In the foetus, the intestinal loops resembled many tubular sections in the abdominal cavity and were covered in columnar epithelium (Figure $4 \mathrm{H}$ ).

The liver was already present in the E1 embryo (Figure 3G). This organ develops at an early stage due to its important function during organogenesis. At this stage, the liver consisted of disorganised hepatoblasts that were surrounded by numerous blood vessels. In the foetus, the large vessels in the liver parenchyma and the central lobular veins could be seen (Figure 4G).

\section{Urogenital System}

The mesonephros in the E1 embryo was elongated and consisted of several tubes. A large amount of mesenchymal tissue was also observed between the tubes, suggesting the possible breakdown, apoptosis, and substitution of the mesonephric tissue (Figure 3I). In F1, the forming metanephros, or definitive kidney, which had an ellipsoid shape and several lobes, was detected. The kidney was multipyramidal, with medullary pyramids that were separated and covered by a single cortex. In the caudal region of the foetus, the formation of two organs with tissue that was similar to that of the kidneys could be observed. These organs will become the embryonic gonads (feminine or masculine) but were only primitive gonads in this case. At this developmental stage, the primitive gonads consisted of glandular tissue that contained numerous internal tubes (Figure 4I).

\section{Discussion}

In this work, we analysed the embryonic and foetal development of Ovis aries after 24,32, and 50 days of gestation. The CR value and/or gestational age can be determined according to either Bryden et al. (1972) or Evans and Sack (1973). In this study, the approximate age of each embryo or foetus was calculated based on Bryden et al. (1972). These authors performed detailed studies on the embryonic development of various domesticated species, including sheep. However, as they report, it is difficult to determine the precise age of every embryo. Thus, several external morphological traits should be included to improve the accuracy of this determination.

Studying the embryonic development of sheep is important for the livestock industry in Brazil, as sheep are socioeconomically important. In addition, sheep are used as models in studies involving cloning (WILMUT et al., 1997), hematopoietic stem cell transplantation (OPPENHEIM et al., 2001), epidemiology (PEZESHKI et al., 2012), polycystic ovarian syndrome(PADMANABHAN; VEIGA-LOPEZ 2013), white matter lesions (BACK et al., 2012), osteoarthritis (AL FAQEH et al., 2012), and cell reprogramming (EZASHI et al., 2012).

Beaudoin et al. (2003) previously described several embryonic and foetal development stages in a number of species. These descriptions include age, corporal changes, increases in size and weight, and the overall development of the systems and organs, which we are able to compare and identify with the size of the embryos and foetus used in this work.

The initial phase of nervous system development in embryos arises from the neural plate, followed by the neural tube. As gestation progresses, the prosencephalon, the mesencephalon, and the rhombencephalon, which represent the three primordial cephalic vesicles, are formed. In our samples, we found the three vesicle types on day 32 of gestation, which is similar to the results previously described by Bryden et al. (1972). Maiorka et al. (2015) described in a 43-days-old bovine embryo the presence of prosencephalon, mesencephalon, and rhombencephalon. In the foetal stage, more complex nervous system development, including the formation 
of the choroid plexus and the initial ossification of the cranial region, was visible through our light microscopy analysis of toluidine blue-stained sections. Structures such as somites were identified in our sample with 24 days and the same structure is formed around day 20-30 in bovine (HALDIMAN, 1981). The development of dura mater in sheep foetus was observed in our work after 50 days of gestation and, in goat, the development starts around day 40 (LUCY et al., 2008).

A non-pigmented optic vesicle was observed in the E1 embryo (on day 24 of gestation). A previous study of equine embryos revealed the presence of optic vesicles with pigmented retinae (FRANCIOLLI et al., 2011) around 30 days of gestation and in bovine around day 37 (GALDOS-RIVEROS, 2012). In our study, the same traits were found in the E2 embryo (on day 32 of gestation approximately).

In bovines, the development of respiratory tract occurs around 20-21 days of gestation. As described in bovine, after 32-34 days old of gestation lung epithelium was observed. In addition, after about 45-46 days, pseudoglandular lung phase with main bronchi is observed (ALBERTO et al., 2012. Furthermore, in equine embryos under 25 days of gestation no lung tissue is visible, but only between $36-49$ days is this structure visible (RODRIGUES et al., 2014; ZABALA, WEINMAN, 1984). In our study, microscopic observation showed the formation in the foetus, but was not possible to identify it in E1. The oral cavity in the E1 embryo and a more developed oral cavity were macroscopically identified in the E2 embryo, as well as identified in 38 days old equine embryo (FRANCIOLLI et al., 2011). In the foetus, we observed trachea, oesophagus, and developed oral cavity with a tongue, reflecting the developmental progress of the oral cavity. In the lower respiratory system, the lung develops from an evagination of the ventral intestinal wall, giving rise to the main primary bronchus. The foetal lung is pseudoglandular, and the main bronchus shows branching (ALCORN et al., 1981). It was observed in our study that the mesenchyme that surrounds the bronchi was differentiating into condensed and loose mesenchyme during this developmental stage.

The cardiovascular system is one of the major systems in the embryo, as it is the first system to begin developing. The heart is the first organ to form and function in the embryo, as it requires oxygen and nutrition to survive and develop (MOORE, 2004). The heart is formed from the mesoderm, which also forms the arteries, veins, lymphatic vessels, all of the blood and lymph cells, the kidneys, the gonads and their ducts, the spleen, and the adrenal cortex (SADLER, 2005). In the E1 embryo, the heart was developing and had forming ventricles and atria. However, in F1 the right and left ventricles, right and left atria, aorta, and ventricular septum were visible, but the pericardial sac was still forming, most likely due to the age of the foetus.

The digestive system begins with the formation of the vitelline envelope that is then incorporated into the embryo to form the primitive intestine, which can be subdivided into anterior, medial, and posterior regions (PESSOLATO et al., 2012). The primitive intestine arises from the buccopharyngeal membrane, which, in turn, originates from two of the primary germ cell layers. Externally, it is formed by the ectoderm, and internally, by the endoderm and ends at the caudal end of the cloacal membrane (the posterior intestinal region covered by endoderm). In our E1 findings, we observed the primitive intestine, the forming intestinal loops and the early formation of the posterior intestine, which will form the epithelium of the bladder, most of the urethra and other urinary system structures. In the foetus, we observed intestinal loops arranged in tubular sections.

The ruminant stomach is composed of three compartments covered with stratified squamous epithelium (rumen, reticulum, and omasum) and a glandular compartment (abomasum), according to Balch (1959). The early development of the ruminant stomach is the same of simple stomachs. The rumen develops as an expansion of the fundus, and a caudal-ventral pocket in the developing rumen forms the reticulum. In our study, we were able to identify a liver bud in E1. During liver development, the hepatic cords begin to differentiate in the parenchyma, and the bile duct coverings are formed. In our results, we found that the liver was present since the beginning stages of embryonic development due to its important functions during organogenesis. The liver consists of unorganised hepatoblasts surrounded by numerous blood vessels (ABREU et al., 2011). In the foetal stage we found hepatocytes, which were identified as polyhedral cells with eosinophilic cytoplasm.

Kidney development occurs in three stages: the pronephros, mesonephros, and metanephros. Out of these stages, the first two are considered to be primitive kidneys, and the last is considered to be the definitive 
kidney. The pronephros, which is located nearest to the cephalic region of the embryo, was not visible in the studied animals. This phase is likely visible in less developed embryos.

Studies on embryonic development in sheep are highly relevant, as these animals are used as models in several fields. In addition, as the production of these animals has

\section{References}

ABREU, D. K.; RODRIGUES, E. A. F.; MONTEIRO, J. M.; FRANCIOLLI, A. L.; COSTOLA-SOUZA, C.; ROBALLO, K. C. S.; AMBRÓSIO, C. E.; MIGLINO, M. A. Microscopic and macroscopic study focusing ray and alizarin on embryonic and fetal development in cats (Felis catus) in different gestational ages. Pesquisa Veterinária Brasileira, v. 31, n. 1, p. 57-66, 2011. doi: 10.1590/S0100736X2011001300010.

ADAMS, D. B. Prenatal transmission of scrapie in sheep and goats: A case study for veterinary public health. Open Veterinary Journal, v. 6, n. 3, p. 194-214, 2016. doi: 10.4314/ovj.v6i3.8.

AL FAQEH, H.; NOR HAMDAN, B. M.; CHEN, H. C.; AMINUDDIN, B. S.; RUSZYMAH, B. H. The potential of intra-articular injection of chondrogenic-induced bone marrow stem cells to retard the progression of osteoarthritis in a sheep model. Experimental Gerontology, v. 47, n. 6, p. 458-464, 2012. doi: 10.1016/j.exger.2012.03.018.

ALBERTO, M. L.; MEIRELLES, F. V.; PERECIN, F.; AMBRÓSIO, C. E.; FAVARON, P. O.; FRANCIOLLI, A. L.; MESS, A. M.; DOS SANTOS, J. M.; RICI, R. E.; BERTOLINI, M.; MIGLINO, M. A. Development of bovine embryos derived from reproductive techniques. Reproduction, Fertility and Development, v. 25, n. 6, p. 907-917, 2012. doi: 10.1071/RD12092.

ALCORN, D. G.; ADAMSON, T. M.; MALONEY, J. E.; ROBINSON, P. M. A morphologic and morphometric analysis of fetal lung development in the sheep. The Anatomical Record, v. 201, n. 4, p. 655-667, 1981. doi: 10.1002/ar.1092010410.

BACK, S. A.; RIDDLE, A.; DEAN, J.; HOHIMER, A. R. The instrumented fetal sheep as a model of cerebral white a great socioeconomic impact, research in this area may contribute to better reproductive yield and, consequently, increased production.

\section{Acknowledgements}

We would like to thank the University of São Paulo for the support.

matter injury in the premature infant. Neurotherapeutics, v. 9, n. 2, p. 359-370, 2012. doi: 10.1007/s13311-012-0108-y.

BALCH, C. C. Structure of the ruminant stomach and the movement of its contents. Proceeding of the Nutrition Society, v. 18, p. 97-102, 1959. doi: 10.1079/PNS19590027.

BEAUDOIN, S.; BARBET, P.; BARGY, F. Developmental stages in the rabbit embryo: guidelines to choose an appropriate experimental model. Fetal Diagnosis and Therapy, v. 18, n. 6, p. 422-427, 2003. doi: 10.1159/000073136.

BRYDEN, M. M.; EVANS, H. E.; BINNS, W. Embryology of the sheep: Extraembryonic membranes and the development of body form. Journal of Morphology, v. 138, n. 2, p. 169-186, 1972. doi: 10.1002/jmor.1051380204.

BUTLER, H.; JUURLINK, B. H. J. An atlas for staging mammalian and chick embryos. Florida: CRC Press, 1987.

CAMPBELL, K. H.; MCWHIR, J.; RITCHIE, W. A.; WILMUT, I. Sheep cloned by nuclear transfer from a cultured cell line. Nature, v. 380, n. 6569, p. 64-66, 1996. doi: 10.1038/380064a0.

CARNEIRO, G. F. Biotecnologia da reprodução na espécie caprina: perspectivas atuais. Revista Brasileira de Reprodução Animal, v. 31, n. 2, p. 268-273, 2007.

COUTINHO, G. C.; SILVA, L. H. V. Manejo reprodutivo dos ovinos: manual técnico. Florianópolis: CIDASC, 1989.

EVANS, H. E.; SACK, W. O. Prenatal development of domestic and laboratory mammals: Growth curves, external features and selected references. Anatomy Histology and Embryology, v. 2, p. 11-45, 1973. doi: 10.1111/j.1439-0264.1973.tb00253.x. 
EZASHI, T.; TELUGU, B. P.; ROBERTS, R. M. Induced pluripotent stem cells from pigs and other ungulate species: an alternative to embryonic stem cells? Reproduction in Domestic Animals, v. 4, p. 92-97, 2012. doi: 10.1111/j.14390531.2012.02061.x.

FOSTER, J. D.; GOLDMANN, W.; HUNTER, N. Evidence in sheep for pre-natal transmission of scrapie to lambs from infected mothers. PloS One, v. 8, n. 11, 2013. doi: 10.1371/journal.pone.0079433.

FRANCIOLLI, A. L. R.; AMBRÓSIO, C. E.; OLIVEIRA, M. F.; MORINI, A. C.; FAVARON, P. O.; MACHADO, M. R. F.; MIGLINO, M. A. South-American hystricomorphs: a comparative analysis of embryological development. Pesquisa Veterinária Brasileira, v. 31, p. 441-446, 2011. doi: 10.1590/S0100-736X2011000500012.

HALDIMAN, J. T. Bovine somite development and vertebral anlagen establishment. Anatomy, Histology and Embryology, v. 10, n. 4, p. 289-309, 1981. doi: 10.1111/ j.1439-0264.1981.tb00695.x.

HAY, W. W. JR.; BROWN, L. D.; ROZANCE, P. J.; WESOLOWSKI, S. R.; LIMESAND, S. W. Challenges in nourishing the intrauterine growth-restricted foetus: Lessons learned from studies in the intrauterine growthrestricted foetal sheep. Acta Paediatrica, v. 105, n. 8, p. 881-889, 2016. doi: 10.1111/apa.13413.

INSTITUTO FNP. Anualpec 2006: anuário da pecuária brasileira. São Paulo: FNP, 2006.

ISHII, Y.; LANGBERG, J. D.; HURTADO, R.; LEE, S.; MIKAWA, T. Induction of proepicardial marker gene expression by the liver bud. Development, v. 134, n. 20, p. 3627-3637, 2007. doi: 10.1242/dev.005280.

GALDOS-RIVEROS, A. C.; REZENDE, L. C.; PESSOLATO, A. G. T.; ZOGNO, M. A.; RICI, R. E.; MIGLINO, M. A. The structure of the bovine yolk sac: a study microscopic. In: MÉNDES-VILAS, A. Current microscopy contributions to advances in science and technology. 1. ed. Badajos: Formatex, 2012. p. 508-515.

JUNQUEIRA, L. C.; CARNEIRO, J. Histologia básica. Rio de Janeiro: Guanabara Koogan, 2008.
LUCY, K. M.; HARSHAN, K. R.; CHUNGATH, J. J.; ASHOK, N. Prenatal development of the cranial meninges in goats. Indian Journal of Animimal Research, v. 42, n. 1, p. 23-28, 2008.

MAIORKA, P. C.; FAVARON, P. O.; MESS, A. M.; SANTOS, C. R.; ALBERTO, M. L.; MEIRELLES, F. V.; MIGLINO, M. A. Vascular alterations underlie developmental problems manifested in cloned cattle before or after birth. PloS One, v. 10, n. 1, p. 1-14, 2015. doi: 10.1371/journal.pone.0106663

MELLOR, D. J. Nutritional and placental determination of fetal growth rate in sheep and consequences for the newborn lamb. British Veterinary Journal, v. 139, p. 307324, 1983.

MOORE, K. L. Embriologia clínica. Rio de Janeiro: Elsevier, 2004.

MORAES, E. P. X.; SANTOS, M. H. B.; FILHO, C. R. A.; NEVES, J. P.; OLIVEIRA, M. A. L.; LIMA, P. F. Avaliação ultra-sonográfica do desenvolvimento embrionário-fetal de ovinos da raça Santa Inês. Ciência Animal Brasileira, v. 9, n. 1, p. 148-155, 2008.

MORRIS, S. T.; MCCUTCHEON, S. N.; REVELL, D. K. Birth weight responses to shearing ewes in early to mid gestation. Journal Animal Science, v. 7, p. 363-369, 2000. doi: 10.1017/S1357729800054825.

MUTINATI, M.; PICCINNO, M.; RONCETTI, M.; CAMPANILE, D.; RIZZO, A.; SCIORSCI, R. Oxidative stress during pregnancy in the sheep. Reproduction in Domestic Animals, v. 48, n. 3, p. 353-357, 2013. doi: 10.1111/rda.12141.

OPPENHEIM, S. M.; MUENCH, M. O.; GUTIÉRREZADÁN, A.; MOYER, A. L.; BONDURANT, R. H.; ROWE, J. D.; ANDERSON, G. B. Hematopoietic stem cell transplantation in utero produces sheep-goat chimeras. Blood Cells Molecules and Diseases, v. 27, n. 1, p. 296308, 2001. doi: 10.1006/bcmd.2000.0378.

PADMANABHAN, V.; VEIGA-LOPEZ, A. Sheep models of polycystic ovary syndrome phenotype. Molecular and Cellular Endocrinology, v. 373, n. 1-2, p. 8-20, 2013. doi: 10.1016/j.mce.2012.10.005. 
PESSOLATO, A. G. T.; MARTINS, D. S.; GALDOSRIVEROS, A.; FONTES, A. M.; AMBRÓSIO, C. E.; RICI, R. E. G.; MAGALHÃES, D. A. R.; CASTILHO-FERNANDES, A.; COVAS, D. T.; MIGLINO, M. A. Microscopic aspects of the yolk sac hematopoiesis from ovine embryos. In: MÉNDES-VILAS, A. Current microscopy contributions to advances in science and technology. 1. ed. Badajos: Formatex, 2012. p. 610-616.

PEZESHKI, A.; AKHLAGHI, L.; SHARBATKHORI, M.; RAZMJOU, E.; OORMAZDI, H.; MOHEBALI, M.; MEAMAR, A. R. Genotyping of Echinococcus granulosus from domestic animals and humans from Ardabil Province, northwest Iran. Journal of Helminthology, v. 87, n. 4, p. 387-391, 2012. doi: 10.1017/ S0022149X1200051X.

PORADA, C. D.; PARK, P. J.; ALMEIDA-PORADA, G.; LIU, W.; OZTURK, F.; GLIMP, H. A.; ZANJANI, E. D. Gestational age of recipient determines pattern and level of transgene expression following in utero retroviral gene transfer. Molecular Therapy, v. 11, n. 2, p. 284-293, 2005. doi: 10.1016/j.ymthe.2004.09.009.

RIBEIRO, L. A. O.; GREGORY, R. M.; MATTOS, R. C. Prenhez em rebanhos ovinos do Rio Grande do Sul. Ciência Rural, v. 32, n. 4, p. 637-641, 2002. doi: 10.1590/ S0103-84782002000400015.
RODRIGUES, R. F.; RODRIGUES, M. N.; FRANCIOLLI, A. L. R.; CARVALHO, R. C.; RIGOGLIO, N.; JACOB, J. C. F.; GASTAL, E. L.; MIGLINO, M. A. Embryonic and fetal development of the cardiorespiratory apparatus in horses (Equus Caballus) from 20 to 115 days of gestation. Journal Cytology \& Histology, v. 5, n. 4, 2014. doi: 10.4172/21577099.1000240 .

SADLER, T. W. Langman embriologia médica. 9. ed. Rio de Janeiro: Guanabara Koogan, 2005.

THEILER, K. The house mouse: development and normal stages from fertilization to 4 weeks of age. Berlin: Springer, 1972.

TOLOSA, E. M. C.; RODRIGUES, C. J.; BEHMER, O. A.; FREITAS NETO, A. G. Manual de técnicas para histologia normal e patológica. 2. ed. São Paulo: Manole, 2003.

WILMUT, I.; SCHNLEKE, A. E.; MCWHIR, J.; KIND, A. J.; CAMPBELL K. H. S. Viable offspring derived from fetal and adult mammalian cells. Nature, v. 385, p. 810813, 1997. doi: 10.1038/385810a0.

ZABALA, L. E.; WEINMAN, D. E. Prenatal development of the bovine lung. Anatomia, Histologia e Embriologia, v. 13, n. 1, p. 1-14, 1984. doi: 10.1111/j.1439-0264.1984. tb00391.x. 